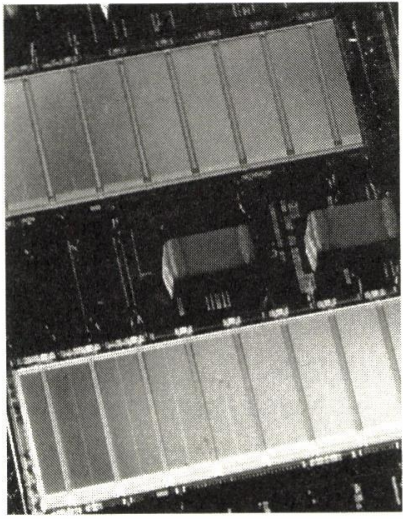

\title{
サーバ/ワークステーション用 MCM
}

MCM for Server/Workstations

\section{福永 尚美* 瀬山 清隆* 菊池 俊一*}

\section{1.はじめに}

ビジネスサーバの K6000シリーズに適用した高性能 な MCM-D テクノロジは, CMOS CHIP を高密度に赛 装する技術として開発したものである。

$\mathrm{MCM}-\mathrm{D}$ 用基板は，窒化アルミニウム板上に銅導体 とポリイミド絶縁体からなる薄膜多層で構成されている。 この上に搭載されるCMOS LSI チップの端子は, 全工 リアにわたってはんだバンプが配列され，ベアチップに よりフェースダウンで薄膜上に接合されている。

MCM-D テクノロジは高速伝送特性, 多数 I/O, 高 性能冷却を可能とし, ワークステーションからメインフ レームにわたる広範囲のコンピュー夕製品に適用できる。 この技術の詳細について，MCM 実装技術，MCM 基 板技術，冷却技術を中心に以下に述べる。

\section{2. 実装技術}

Fig.1に，K6000シリーズビジネスサーバに適用した MCM を示す。使用したテクノロジは MCM-D に分類 される。実装仕様の概略をTab.1に示す。また, Fig.2 に実装構造の概念図を示す。

厚膜導体のない無垢の窒化アルミニウムのべース基板 上に，銅を導体，ポリイミドを絶緑体として交互に形成 されている。それに $0.5 \mu \mathrm{m}$ プロセス $\mathrm{CMOS}$ のエリアバ ンプ LSI チップ, 抵抗・コンデンサ等のチップ部品, I/ $\mathrm{O}$ ピンが搭載される。これらの部品はすべて同一面に春

* Naomi Fukunaga, Kiyotaka Seyama, Shun-ichi Kikuchi 富土通蚮テクロノジ開発部 /FUJITSU LIMITED

Vol.10, No. 5

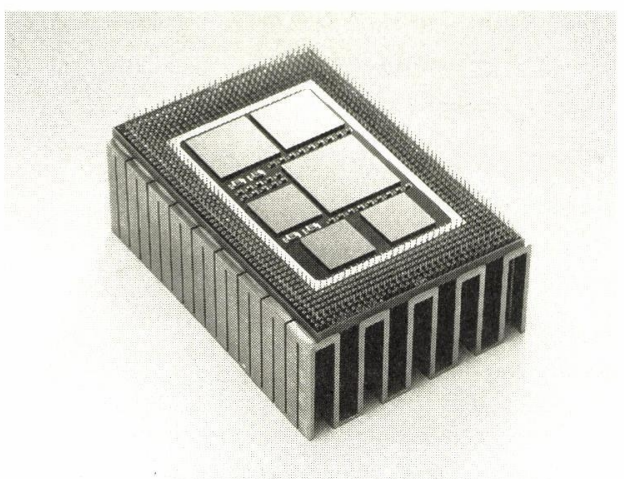

\begin{tabular}{|l|l|}
\hline Outer dimension & $48 \mathrm{~mm} \times 67 \mathrm{~mm} \times 27 \mathrm{~mm}$ \\
\hline MCM substrate & Aluminum nitride \\
\hline Number of chips & 6 pieces (3 sizes) \\
\hline Number of transistors & $12.5 \mathrm{MTr}$ \\
\hline Number of bumps & 6436 (sig.1556) \\
\hline Number of I/Opins & 719 (sig.355) \\
\hline Heat dissipation & 18.8 Watts \\
\hline
\end{tabular}

Fig.1 Photograph of MCM applied to FUJITSU K6000 Series business server.

Tab.1 MCM packaging feature.

\begin{tabular}{|c|c|c|}
\hline LSI chip & $\begin{array}{l}\text { Flip chip bonding } \\
\text { Area bump interconnection } \\
\text { Bump pitch }-210 \mu \mathrm{m}\end{array}$ & \\
\hline $\mathrm{I} / \mathrm{O}$ pin & $\begin{array}{l}\text { Surface mount pin grid array } \\
\text { Butt soldering connection } \\
\text { Pin pitch }-1.27 \mathrm{~mm} \text { grid } \\
0.635 \mathrm{~mm} \text { staggered } \\
\text { Mixed above }\end{array}$ & selectable \\
\hline
\end{tabular}




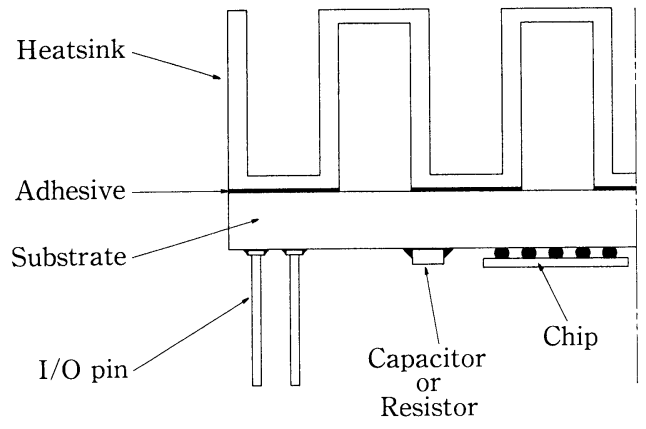

Fig.2 MCM packaging structure.

装されるため，裏面には大型のヒートシンクを接合し， 高発熱の冷却ができる。

LSI チップには, 直径約 $100 \mu \mathrm{m}$ の $\mathrm{Pb}$ 樂の高温はんだ バンプが $210 \mu \mathrm{m}$ ピッチで全エリアに配列されている。

MCM は，表面実装ピングリッドアレイのI/O ピン によりプリント基板へはんだ付け実装される。 MCMの $\mathrm{I} / \mathrm{O}$ ピンの配列は50mil $(1.27 \mathrm{~mm})$ 格子配列, $25 \mathrm{mil}$ (0.635mm) 千鳥配列，および $50 \mathrm{mil}$ 格子 $/ 25 \mathrm{mil}$ 千鳥の 混在したものが可能である。

このため, 設計者は LSI チップと MCM の I/O ピン の配置設計の自由度が大きい。

$\mathrm{Tab} .2$ にチップの許容入出力総数を示す。 $15 \mathrm{~mm} \times 15$

\begin{tabular}{l|l} 
Tab.2 Allowable I/O counts for chips. \\
\hline Bump density & $\begin{array}{l}\text { Number of } \\
\text { bumps for } \\
15 \mathrm{~mm} \times 15 \mathrm{~mm}\end{array}$ \\
\hline $2267 / \mathrm{cm}^{2}$ & $4900 \mathrm{max}$. \\
\hline
\end{tabular}

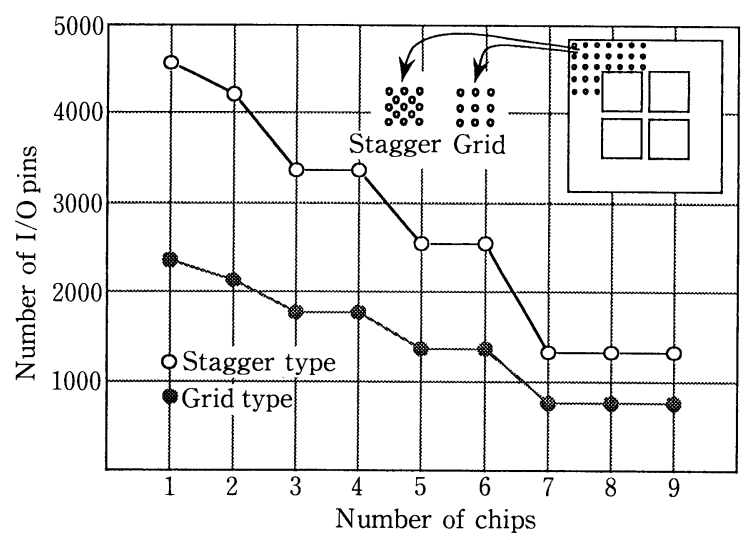

Fig.3 The relation between total I/O counts for a $67 \mathrm{~mm} \times 67 \mathrm{~mm}$ substrate and number of chips mounted for the substrate. $\mathrm{mm}$ の LSI チップで最大 4,900 のはんだバンプが確保で きる。また, Fig.3に基板の入出力総数とチップの数の 関係を示す。 $67 \mathrm{~mm} \times 67 \mathrm{~mm}$ 基板上に $15 \mathrm{~mm} \times 15 \mathrm{~mm}$ の チップを 4 ケ搭載した場合, $50 \mathrm{mil}$ 格子で約 1,700 入 出力ピンが確保できる。

このように本 MCM は特にチップと基板に多数の入 出力ピンを許容できる。

また，本 MCM の部品実装は，高信頼性を得られる ように実装設計，プロセス設計されている。

たとえば，I/O ピンの接合部はピンに低ヤング率材料 を採用し，数值解析や評価試験を通してピンの直径と長 さははんだ接合部のフィレット形状を最適化することに よって高信頼度を確保している。LSI チップのはんだバ ンプ接合部も, 解析・試験によって, チップ下部へのポ ッティングの有無に関係なく長期的信頼度を満足するこ とを検証している。信頼性評価の概略を以下に示す。

\section{SMPGA 接合の信頼性評価}

$45 \mathrm{~mm} \times 67 \mathrm{~mm} \times 2 \mathrm{~mm}$ の薄膜 5 層基板に 719 本の I/O ピンを実装し，基板裏面にはフィンを接着した。この $\mathrm{MCM}$ を厚さ1.6mm の FR4プリント基板上にはんだ付 けしたサンプルを使用して, 液相の熱衝撃試験, 振動試 験, 機械的衝撃試験, はんだクリープ試験を行い，15年 以上の実稼働で問題ないことを確認した。

\section{バンプ接合の信頼性評価}

2,401個のバンプをもつ $13 \mathrm{~mm} \times 13 \mathrm{~mm}$ の LSI チップ, および3,035個のバンプをもつ $16 \mathrm{~mm} \times 16 \mathrm{~mm} の \mathrm{LSI}$ チ ップを， $45 \mathrm{~mm} \times 67 \mathrm{~mm} \times 2 \mathrm{~mm}$ の薄膜 5 層基板に実装し たサンプルを使用し, $-65^{\circ} \mathrm{C} /+125^{\circ} \mathrm{C}$ の液相の熱衝撃試 験により評価し，15年以上の実稼働で問題ないことを確 認した。

\section{3. $\mathrm{MCM}$ 基板テクノロジ}

MCM-D の基板材料としてはシリコンを使った適用 事例等があるが1)，新しく開発した MCM 基板は以下の 理由から窒化アルミニウムを採用した。

(1) Siチップと熱的整合の取れた線膨張係数のため, チップと基板とのはんだ接合部に高い信頼性を確保 できる。

(2)チップの熱流束を一様に広げる高い熱伝導率である ため，基板の高温箇所を除去し，ヒートシンクの冷 却性能を高めることができる。

(3)高いヤング率のため, 熱挙動に対して反りを小さく 抑えられる。 


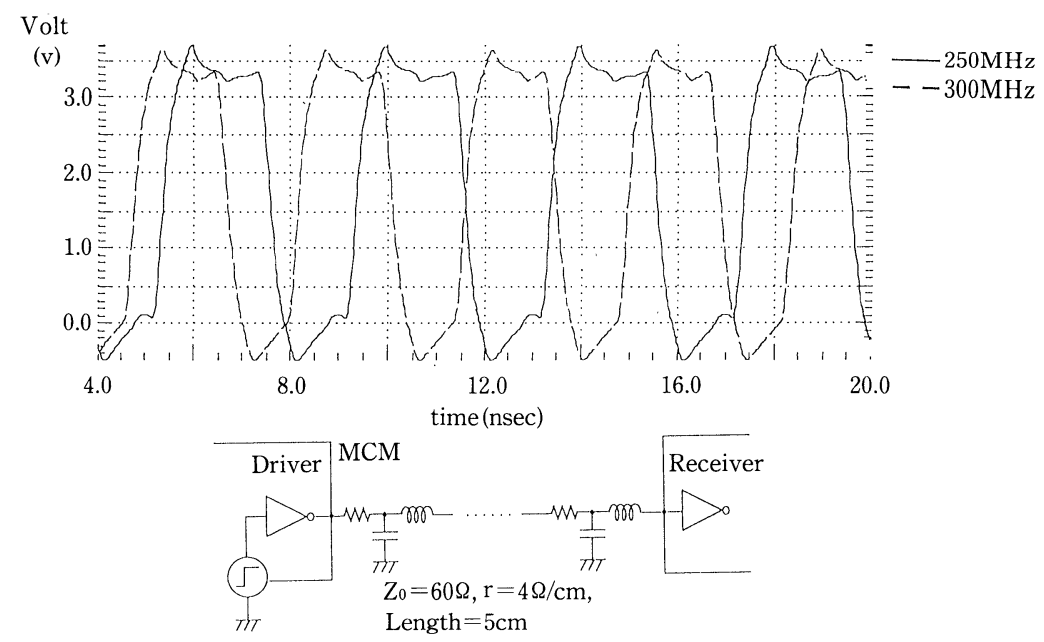

Fig.5 Used analysis model and signal transmission wave inside an MCM.

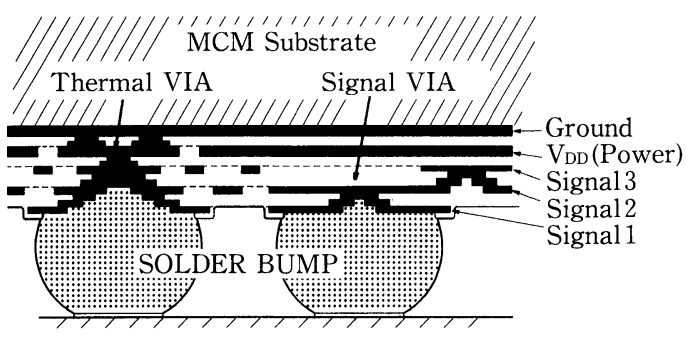

Chip

Fig.4 Cross sectional view of the MCM substrate.

また， MCM 基板の最大サイズは $135 \mathrm{~mm} \times 135 \mathrm{~mm}$ で， さまざまなサイズの MCM 基板を顧客の要求に対して 提供することができる。

ベース基板の窒化アルミニウムにはビアとパターンが 全くないため，窒化アルミニウムの代りに他の材料を使 用することが可能である。たとえば，MCM の発熱量や 実装チップのサイズの信頼度を考慮して一般のアルミナ セラミック基板や金属基板を応用することができる。

現行の $\mathrm{MCM}$ パターン設計ルールは, 最小パターン 幅 $12 \mu \mathrm{m}$ ，最小パターンピッチ $27 \mu \mathrm{m}$ ，最大パターン厚 5 $\mu \mathrm{m}$ である。層間の接続ビアの最小サイズは $20 \mu \mathrm{m} の 八$ 角形である。また，一般的に 5 層板であるが，何層板に するかは配線密度の要求に従って自由に選択することが

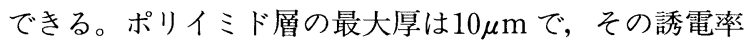
は3.5である。Fig.4に MCM 基板の断面構造を示す。

なお，今後予想される高密度配線要求対策として，多 くのチャネルを保証するための新しいパターン形成テク ノロジを開発中である。

Vol.10, No. 5
次に，製品に使用されているこの基板の電気特性を以 下に示す。電源層とグランド層のシート抵抗は $4 \mathrm{~m} \Omega /$ ロ で，パターン抵抗は $4 \Omega / \mathrm{cm}$, 電気容量は $0.8 \mathrm{pF} / \mathrm{cm}$ であ る。また，特性インピーダンスは絶縁層，パターン形状

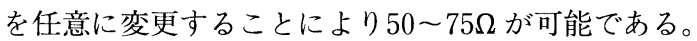

導体に低抵抗である銅と，絶縁体に $\tan \sigma$ が小さいポ リイミドを使用していることにより, 今後要求される $250 \mathrm{MHz}$ 以上の高速伝送系 MCM にも本構造で適用可 能である。Fig.5に解析モデルと MCM 内の信号伝送シ ミュレーション結果を示す。なお，解析に用いた $\mathrm{MCM}$ 内のパターン長は $5 \mathrm{~cm}$ である。

\section{4. 冷却技術}

LSI の長期的な信頼性を維持し，MCM を安定に稼働 させるために冷却にも工夫を凝らした。高発熱を許容し， 安定動作を保証するためにはチップジャンクションから 周囲冷媒（主に空気）に至る熱抵抗 $R_{j-a}$ をできるだけ 小さくすることと，チップ内部およびチップ間の温度差 を一定範囲に抑えることが重要である。 MCM の熱抵抗 $R_{j-a}$ は以下の式で表される。

$$
R_{j-a}=R_{j-c}+R_{c-a}
$$

$R_{j-c}$ は MCM 内部の熱抵抗で，はんだバンプ, 薄膜 ビア，ベース基板の熱抵抗が含まれる。 $R_{c-a}$ は使用さ れる環境下での周囲冷媒から MCM 表面までのヒート シンクを含む熱抵抗である。

$R_{j-c}$ を低減するには，LSI チップのはんだバンプ数の 増加以外に薄膜ビア自体の熱抵抗低減が必要である。 $R_{c-a}$ を低減するには接合材の熱伝導率向上とヒートシ 


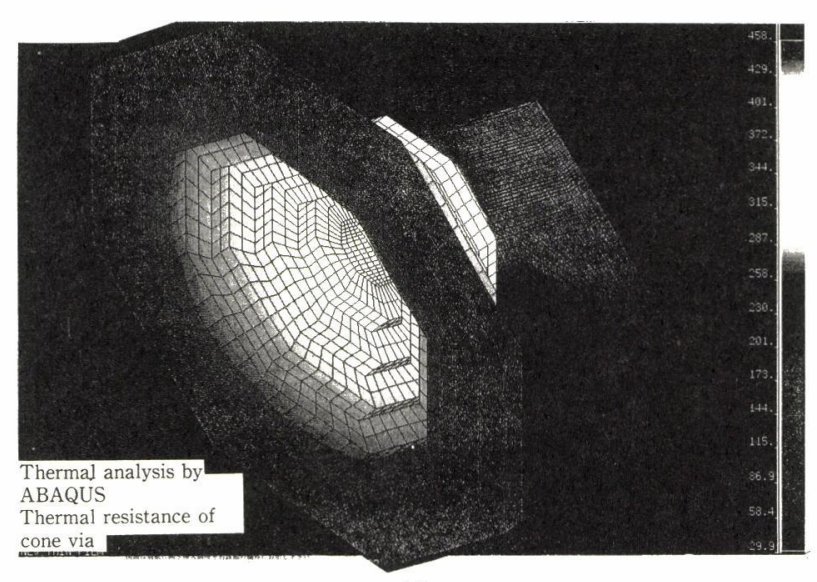

(a)

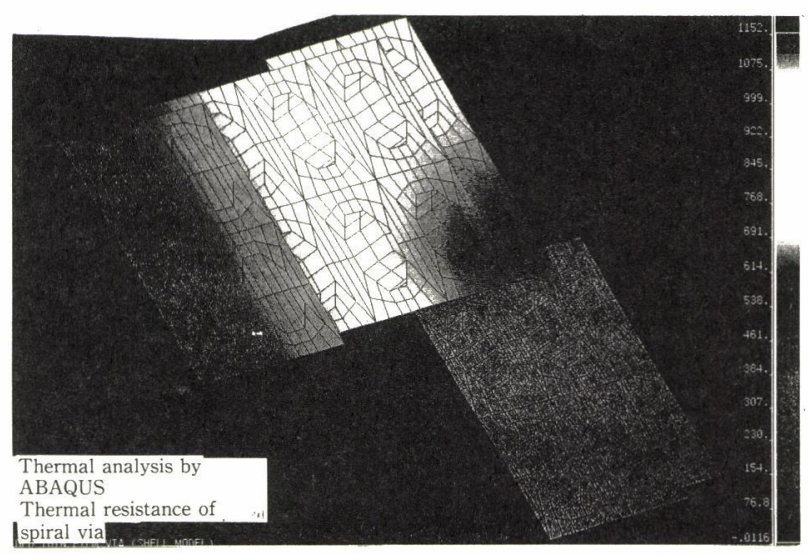

(b)

Fig.6 Temperature contour map of cone via and spiral via.

\section{ンク自体の高性能化が必要である。}

まず，薄膜ビアの最適化の例を示す。絶縁層であるポ リイミドの熱伝導率が極めて小さいため, 最も効果の高 いべース基板に近いグランド層・電源層に接合されるビ アの熱抵抗低減を検討した。Fig.6は有限要素法による ビアの熱伝導解析結果の一例である。(a)が各層でビアを 乗り換えるスパイラル型，(b)がグランド層または電源層 から垂直につなげた円錐型である。解析結果では，円錐 型のほうがスパイラル型の半分以下の熱抵抗であり，実 際に製品に適用されている。

次にヒートシンクを説明する。これは低風速で泠却性 能の高いフィンであり，アルミニウム合金を使用してい る。高さ $22 \mathrm{~mm}$ の標準的フィンで手前風速 $1 \mathrm{~m} / \mathrm{s}$ で 0.7 $\mathrm{W} / \mathrm{cm}^{2}$ の冷却を許容できる。フィンの天井部は冷却風 の上方への逃げを防ぎ，側面のスリットはフィン $(\alpha=$ $23.8 \mathrm{ppm})$ と窒化アルミニウム $(\boldsymbol{\alpha}=4.6 \mathrm{ppm})$ の線膨 32

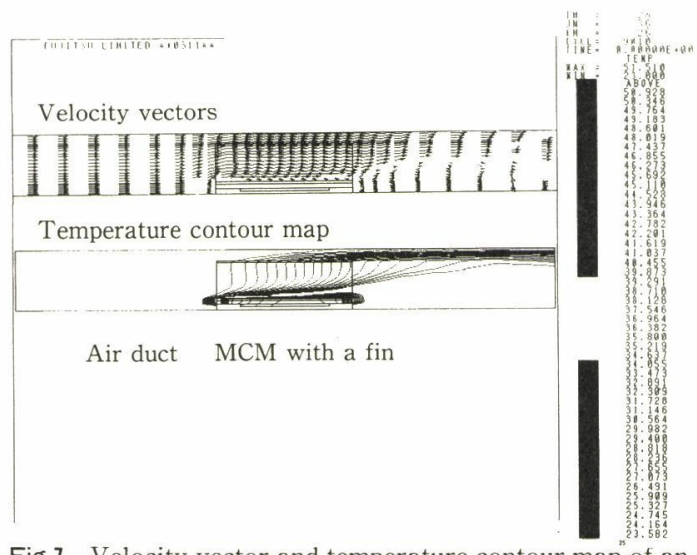

Fig.7 Velocity vector and temperature contour map of an MCM by Computational Fluid Dynamics analysis.

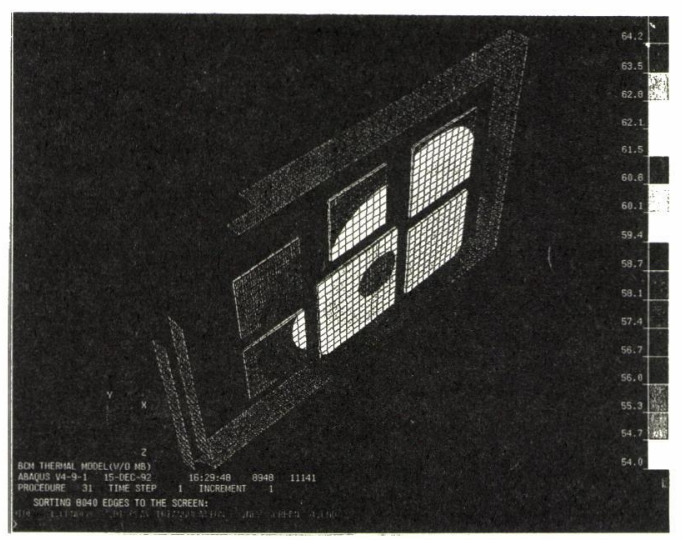

Fig.8 Temperature contour map on the surface of an MCM.

張係数の差で接合部に発生する熱応力を緩和している。 フィンは押し出し成形，またはダイカストで製造される。 フィン厚とフィン間スペースは熱流体解析により, 形状 最適化を行った。Fig.7は MCM の1/2モデルであり, 流 線と等温線図を示す。最終段階で MCMレベル，ボー ド搭載レベルの熱解析・評価を実施し, 最終的な検証を 行った。Fig.8は MCM の熱解析結果を示す。

さらに本 MCM は冷却構造を改善することで,より 高い発熱密度を許容できる。Fig.9は67 $\mathrm{mm} \times 67 \mathrm{~mm} の$ MCM 基板に $15 \mathrm{~mm} \times 15 \mathrm{~mm}$ の LSI チップを 4 ケ搭載し, 周囲温度 $35^{\circ} \mathrm{C}, \mathrm{MCM}$ 手前までの空気温度上昇を $5{ }^{\circ} \mathrm{C}$, ジャンクション温度 $85^{\circ} \mathrm{C}$ と仮定した場合の許容発熱密度 を示す。各 LSI チップのはんだバンプは 4,000 個と仮定 した。標準フィンの緻密化で手前風速 $3 \mathrm{~m} / \mathrm{s}$ 時に $2.0 \mathrm{~W} /$ $\mathrm{cm}^{2}$ 以上, ヒートパイプ, マイクロチャネル, コールド プレートを採用することで $4.0 \mathrm{~W} / \mathrm{cm}^{2}$ 以上の発熱密度ま $S H M$ 会誌 

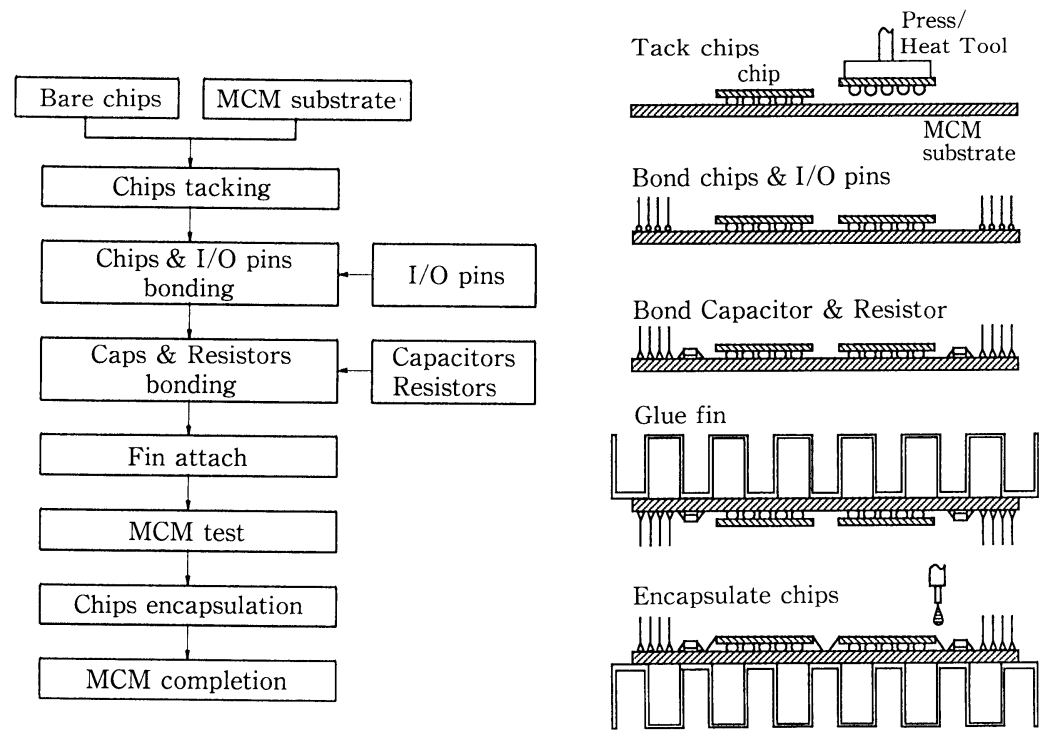

Fig.10 Flowchart of MCM assembly process.

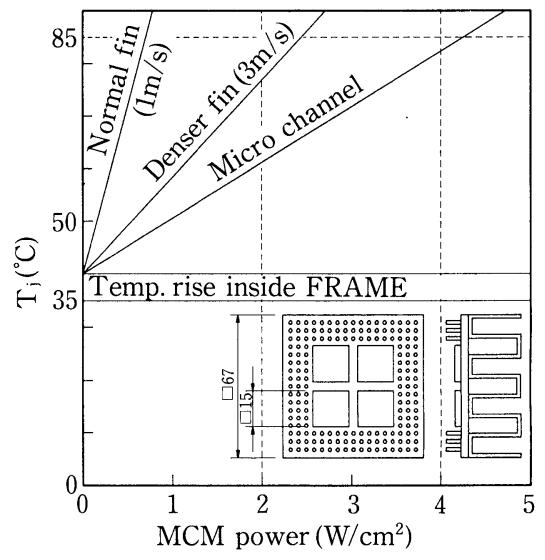

Fig.9 Allowable heat density for a $67 \mathrm{~mm} \times$ $67 \mathrm{~mm}$ substrate mounted with four $15 \mathrm{~mm} \times 15 \mathrm{~mm}$ chips.

で許容できることを実験レベルで検証済である。

\section{MCM 実装プロセス}

Fig.10に MCM 実装プロセスのフローを示す。また， Fig.11に MCM の試験にかかわるフローを詳述する。 Burn-in 試験済の LSI チップは電気試験済の MCM 基板に仮圧着される。次に $\mathrm{I} / \mathrm{O}$ ピンを治工具で位置出 しし，LSI チップとともに $\mathrm{H}_{2}-\mathrm{N}_{2}$ のベルト炉でフラッ クスレス接合する。その後, 抵抗・コンデンサのチップ Vol. 10, No. 5

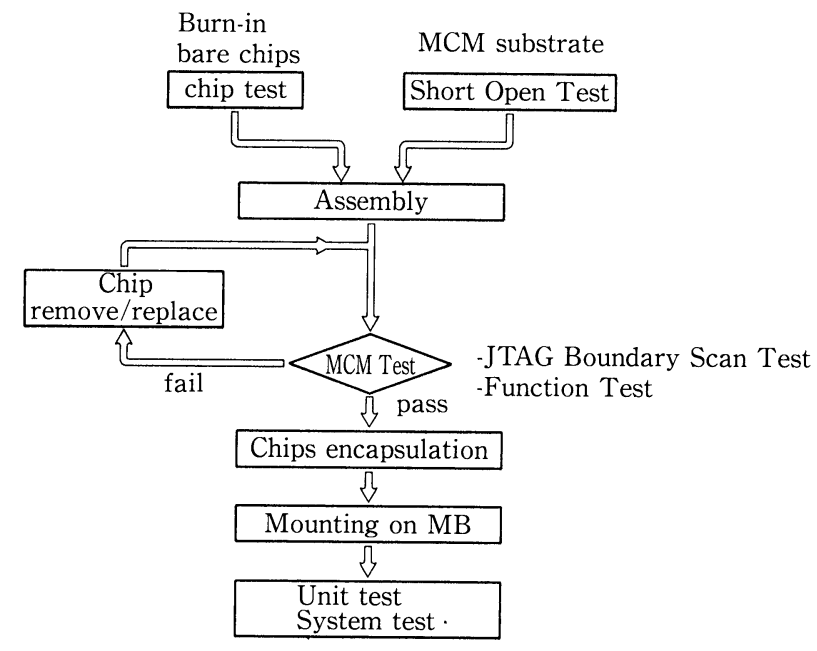

Fig.11 Detailed flowchart of MCM test.

部品を接合し，裏面に冷却フィンを良熱伝導の接着剂で 固定する。MCM は外観検査・電気試験を行い，合格後 に樹脂またはフタで封止する。試験不合格の場合には異 常 LSI を交換する。

\section{6.おわりに}

窒化アルミニウム基板上に銅とポリイミドからなる薄 膜多層配線を有する高性能 MCM-D テクノロジを開発 した。またここのテクノロジを富士通 K6000シリーズ 
ビジネスサーバのプロセッサモジュールに採用した。 特徵として, 高速伝送・多数 $\mathrm{I} / \mathrm{O}$ ・高発熱を許容でき る。

MCM-D はワークステーション・サーバからスーパー コンピュータ・並列処理コンピュータに至る幅広い性能 範囲をカバーできるテクノロジである。したがって，今 後はローコスト化と高性能化の 2 系統で開発を進める必 要があろう。

高性能化には低誘電率絶縁材料を使い, さらに配線を 微細化した基板の開発や高発熱を許容するヒートシンク の開発が望まれる。

ローコスト化では基板と冷却が大きなテーマである。 基板側では金属基板の採用，パ夕ーン仕様の緩和，ある いは高密度化による薄膜層数の削減，冷却側ではプリン 卜板等周囲への熱放散, 簡易形状ヒートシンクの採用な どが必要となろう。

\section{参 考 文 献}

1) M. Y. Lau, K. L. Tai, R. C. Frye, M. Saito and D. D. Bacon: 「A Versatile, IC Process Compatible MCM-D for High Performance and Low Cost Applications」, Proceedings of the 1993 INTERNATIONAL CONFERENCE AND EXHIBITION ON MULTICHIP MODULES, p.107-112

2) S. Kikuchi, H. Yamamoto, K. Seyama, M. Hirano, K. Moriizumi : 「High Performance MCM-D Technology」, Proceedings of 1994 IEEE Multi-Chip Module Conference, p.9-14

3）大嶋 修, 吉村英明：「MCM パッケージ及び MCMの PWB への最適実装」，表面実装技術，1994年7月号

福永尚美（ふくながなおみ）

\section{〔執筆者紹介〕}

1993年，富士通(株)入社。以来，実装技術の開発に従事。 瀬山清隆 (せやまきよたか)

1976年，富士通侏入社。以来，実装技術の開発に従事。 菊池俊一（きくち しゅんいち）

1981年，富士通株入社。以来，実装技術の開発に従事。

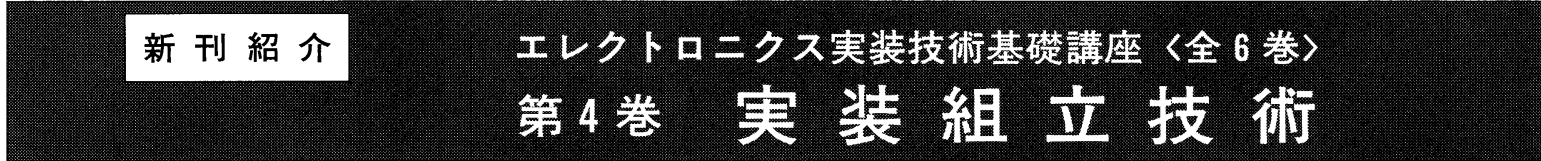

- 侏工業調査会 (1994年 7 月発行)

\section{- 社団法人 SHM 編}

- A 5 判 $/ 272$ 頁 $/$ 定価3,605円

本格的なマルチメディア時代の到来とともに，LSI の 大容量化, 多ピン化, 高速化, システムオンチップ化お よび商品側からのコンパクト化，使い易さへの要求に伴 う実装技術への課題は，材料・プロセス・装置いずれの 面でも大きくかつ重くなっている。

このような状況の中で実装技術者には，今までと質の 違うインテリジェンスと自らの実装思想に基づく大胆な 発想が今後一層要求され，この姿勢と実践こそが，次世 代の商品性を高めることとなるように思われる。

そこでSHM では協会創立25周年を記念して「エレク トロニクス実装技術基礎講座（全 6 卷）」を刊行するこ とにし，まず第 1 卷《総論》と第 3 卷《膜回路形成技 術》が発刊された ('94年 2 月)。

今回その第 2 弾として第 4 巻が刊行されたので，概略 内容を紹介し，活用をおすす抄する。

第 4 巻《実装組立技術》は，いわゆる“アセンブル” と称される領域を対象とし，SMTやリードスルー実装 などの LSI パッケージの搭載から各種ベアチップ実装, $\mathrm{MCM}$ 実装に至るまで幅広くデバイス搭載技術を解説す
るとともに，基板と基板との接続についても詳述してあ る。いずれも「基礎」に重点をおいているが，その技術 の背景（歴史）や応用例，技術開発の成果も取り入れて いる。

執筆陣は，エレクトロニクス実装技術の最先端に立つ て活躍されている方々で，これから実装技術分野に携わ ろうとする方はもちろん，エレクトロニクスに何らかの 形で関わる方々にも，好適な参考書である。

\section{目次}

(1) 概 論一半導体デバイス，一般電子部品の実装技 術一

(2) パッケージ LSI，一般電子部品の実装技術

(3) ベアーチップの実装技術

(4) マルチチップモジュール (Multi Chip Module: $\mathrm{MCM}$ ) 技術

(5) 半導体デバイスの封止技術・材料

(6) 基板間接続技術

\section{〈今後の分冊発刊予定〉}

第 2 巻 実装基板

第 5 卷 搭載部品

第 6 巻 設計・信頼性評価技術
1995年 1 月 刊行予定 1995年 1 月 刊行予定 1995年 1 月 刊行予定 